\title{
Growth and photosynthesis responses of two co-occurring marsh grasses to inundation and varied nutrients
}

\begin{tabular}{|r|l|}
\hline Journal: & Botany \\
\hline Manuscript ID: & cjb-2015-0055.R1 \\
\hline Manuscript Type: & Article \\
\hline Date Submitted by the Author: & 11 -Jun-2015 \\
\hline Complete List of Authors: & $\begin{array}{l}\text { Watson, Elizabeth; Drexel University, Academy of Natural Sciences } \\
\text { Andrews, Holly; University of Michigan, Ecology and Evolutionary Biology } \\
\text { Fischer, Amy; Arkansas State University, } \\
\text { Cencer, Morgan; Michigan Technological University, } \\
\text { Coiro, Laura; U.S. Environmental Protection Agency, Atlantic Ecology } \\
\text { Division, ORD-NHEERL } \\
\text { Kelley, Sean; U.S. Environmental Protection Agency, Atlantic Ecology } \\
\text { Division, ORD-NHEERL } \\
\text { Wigand, Cathleen; U.S. Environmental Protection Agency, Atlantic Ecology } \\
\text { Division, ORD-NHEER }\end{array}$ \\
\hline Keyword: & eutrophication, salinity, marsh loss, New England, sea level rise \\
\hline \multicolumn{2}{|c}{} \\
\hline
\end{tabular}


(I) Growth and photosynthesis responses of two co-occurring marsh grasses to inundation and varied nutrients

(II) Elizabeth Burke Watson ${ }^{\bigotimes 1,2}$, Holly M. Andrews ${ }^{3}$, Amy Fisher ${ }^{4}$, Morgan Cencer ${ }^{5}$, Laura Coiro $^{6}$, Sean Kelley ${ }^{7,8}$, Cathleen Wigand ${ }^{9}$

(III) ${ }^{1}$ Atlantic Ecology Division, ORD-NHEERL, U.S. Environmental Protection Agency, Narragansett, RI, USA;

${ }^{2}$ present address: Biodiversity, Earth \& Environmental Sciences Department, Academy of Natural Sciences of Drexel University, Philadelphia, PA, USA;

elizabeth.b.watson@drexel.edu

${ }^{3}$ Dept. of Ecology and Evolutionary Biology, University of Michigan, $\square$ Ann Arbor, MI, USA; andrewhm@umich.edu

${ }^{4}$ Arkansas State University, Jonesboro, AR, USA; aef917@gmail.com

${ }^{5}$ Chemistry Department, Michigan Technological University, Houghton, MI, USA; mmowencr@mtu.edu

${ }^{6}$ Atlantic Ecology Division, ORD-NHEERL, U.S. Environmental Protection Agency, Narragansett, RI, USA; coiro.laura@epa.gov

${ }^{7}$ Atlantic Ecology Division, ORD-NHEERL, U.S. Environmental Protection Agency, Narragansett, RI, USA; $\underline{\text { skelley27@,my.uri.edu }}$

${ }^{8}$ Natural Resources Science Department, University of Rhode Island, Kingston, RI, USA

${ }^{9}$ Atlantic Ecology Division, ORD-NHEERL, U.S. Environmental Protection Agency, Narragansett, RI, USA; Wigand.Cathleen@epa.gov 
(IV) $\triangle^{-}$For correspondence: Elizabeth Burke Watson, Academy of Natural Sciences of Drexel University, 1900 Benjamin Franklin Pkwy, Philadelphia, PA 19103, USA, Email

elizabeth.b.watson@gmail.com; voice +1 215-299-1109; fax +1 215-299-1182 


\begin{abstract}
For tidal marshes of the U.S. Northeast, the late twentieth century decline of Spartina patens has been attributed to increased flooding associated with accelerated sea level rise and nitrogen over-enrichment from cultural eutrophication. The objective of this study was to examine the impacts of inundation and nutrient availability on growth, photosynthesis, and interactions of Spartina patens and Distichlis spicata, which co-occur and are common marsh species. Plants were grown in a factorial greenhouse experiment, where flow-through seawater was used to simulate semi-diurnal tides. Field surveys were additionally conducted to relate plant distributions to environmental conditions. For Spartina patens grown in monoculture, nutrient additions did not enhance growth for the high inundation treatment. In addition, the combination of high nutrient availability and high inundation adversely affected S. patens tiller density, photosynthetic efficiency and leaf $\mathrm{CO}_{2}$ uptake. For Distichlis spicata, nutrient additions enhanced growth for both inundation treatments with respect to aboveground biomass and tiller density. For species pairings, S. patens expanded relative to D. spicata under low inundation, low nutrient availability conditions, but declined relative to D. spicata under daily inundation in combination with nutrient amendments. These findings were additionally supported by field data, which indicated that D. spicata was more common than $S$. patens where nutrient availability was high. These results suggest that $S$. patens persistence is favored by low nutrient inputs and well-drained conditions, and supports the interpretation that this species is vulnerable to loss where high nutrient loads coincide with accelerated sea level rise.
\end{abstract}

Keywords: eutrophication, salinity, marsh loss, New England, sea level rise 


\section{INTRODUCTION}

Healthy tidal wetlands provide a wide variety of economic, cultural, ecological, and aesthetic benefits to coastal communities, including protection from coastal flooding and shoreline stabilization, water quality improvements for adjacent marine and estuarine habitats, carbon sequestration, recreational opportunities, and provision of habitat for protected fauna (Kennish 2001; Millenium Ecosystem Assessment 2005). However, coastal marshes occupy a narrow elevation range, transitional in nature between terrestrial and marine ecosystems, making them sensitive to impacts originating from both upland and adjacent marine systems (Reed 1995; Roman et al., 2000).

Historically, the ecosystem dominant for New England tidal marshes was the plant species Spartina patens (Aiton) Muhl. Botanical descriptions of Long Island and New England tidal marshes dating from the early through mid twentieth century describe S. patens as the most common plant species (e.g. Taylor 1938; Miller and Egler 1950; Nixon 1982), and scientific studies addressing other aspects of marsh ecology from the era also portray marshes in the region as dominated by S. patens (Knight 1934; Chapman 1940; Butler 1959). However, recent reports have noted significant declines in the abundance and distribution of S. patens in New England marshes. Analysis of historic aerial photographs for Long Island Sound and Cape Cod indicate an ongoing loss of S. patens (Civco et al., 1986; Smith 2009; Smith 2015), while a combination of vegetation re-surveys and peat core analyses demonstrate the contemporary disappearance of $S$. patens in Rhode Island, Massachusetts, New York, and Connecticut marshes (O'Connor and Terry 1972; Niering and Warren 1980; Warren and Niering 1993; Roman et al., 1997; Donnelly and Bertness 2001; K Raposa, NBNERR, Prudence Island, RI, unpubl. res.)

This decline in $S$. patens has been attributed to a combination of nutrient overenrichment due to cultural eutrophication and increased inundation resulting from 
accelerating sea level rise (Warren and Niering 1993; Bertness et al., 2002). While S. patens has a broad ecological range (Silander and Antonovics 1979), and is competitively dominant under well-drained conditions (Bertness 1991), studies show that fertilization does not subsidize growth of S. patens under saline conditions (Foret 2001; Merino et al., 2010). Thus, nutrient subsidies may alter competitive dynamics to the detriment of $S$. patens. Interpreting widespread loss of $S$. patens as a function of nutrient over-enrichment is supported by comparative analyses of nutrient availability and $S$. patens abundance in plotlevel experiments (Levine et al., 1998; Emery et al., 2001), and in comparative analyses of marshes receiving a range of nutrient inputs from very low to very high (Bertness et al., 2002; Wigand et al., 2003; Wigand 2008). At both the plot and landscape scale, S. patens is less abundant under conditions of high nutrient availability.

In addition to nutrient loads altering competitive interactions, marshes in the U.S. Northeast are experiencing inundation increases related to storm surges (Sweet et al., 2011) and accelerated sea level rise (Kopp 2013). The U.S. Atlantic coast between Cape Hatteras and Cape Cod has been experiencing sea level rise rates over the past three decades that are three to four times the global average (Sallenger et al., 2012); an observation that has been attributed to spatial changes in ocean dynamics primarily related to the position and strength of the Gulf Stream (Ezer et al., 2013). In comparison with other common wetland species, $S$. patens is extremely sensitive to inundation (Gleason and Zieman 1981; Broome et al., 1995; Spalding and Hester 2007), as its root aerenchyma cannot provide sufficient oxygen to support aerobic respiration under fully flooded conditions (Burdick and Mendelssohn 1990; Pezeshki et al., 1991). Increased inundation has been proposed as the main causative factor for S. patens loss, as declines are noted for lower elevation plots, while higher elevation plots appear stable (Warren and Niering 1993; Smith et al., 2012; K Raposa, NBNERR, Prudence Island, RI, unpubl. res.). Additionally, dieback of $S$. patens is occurring in the absence of 
competitive displacement (Smith 2009; Smith et al., 2012), suggesting that nutrient-related competitive shifts are playing a limited role in the overall decline of S. patens.

In this study, our main objective was to elucidate controls on the growth of Spartina patens, and to provide a comparison with a common and co-occurring species (Distichlis spicata). We examined the interactive effects of inundation and nutrient availability on the photosynthesis and growth of two co-occurring high marsh species, Distichlis spicata and Spartina patens, grown in monoculture, and as species mixtures over a three-month experimental period. While declines in $S$. patens have been reported for the region for decades (Nixon 1982; Civco et al., 1986), these declines are currently a focus of particular concern for the coastal conservation and management community. This is because the salt marsh sparrow (Ammodramus caudacutus; IUCN red-listed and considered vulnerable to extinction) is an obligate coastal marsh breeding bird, and within coastal marshes breeds primarily among the species Spartina patens (Elphick et al., In Press). Because both inundation and high nutrient loads have been linked to the reduced abundance of $S$. patens at field sites (Warren and Niering 1993; Donnelly and Bertness 2001; Wigand et al., 2003), an improved understanding of the extent to which $S$. patens declines are driven by high nutrient loads associated with coastal development versus accelerated sea level rise may help coastal managers in the accurate targeting of intervention efforts.

\section{MATERIALS AND METHODS}

\section{Plant and soil material}

Sod monocultures and mixtures of Spartina patens and Distichlis spicata were collected 5 June 2012 from Pettaquamscutt Cove, John H. Chaffee National Wildlife Refuge, Narragansett, Rhode Island $\left(41.44^{\circ} \mathrm{N}, 71.46^{\circ} \mathrm{W}\right)$. Sods were separated into 6 x 6 x $20 \mathrm{~cm}$ plugs for planting. Soil was a mixture of native marsh soil and soil used previously for 
plant propagation, homogenized using a cement mixer. Plugs were planted into this soil and watered daily until 13 June 2012 as an acclimatization period.

\section{Experimental procedures}

Sods were propagated during the summer growing season in six $700 \mathrm{~L}$ tanks (circular, $130 \mathrm{~cm}$ diameter by $60 \mathrm{~cm}$ height) with simulated semi-diurnal tides located within a greenhouse (Fig. 1). The experiment used a $2 \times 2 \times 3$ factorial design, replicated six times, for a total of 72 experimental units. Two inundation regimes were created by housing pots at two elevations (Fig. 1). The low inundation treatment was $15 \mathrm{~cm}$ above the high tide and never received surface inundation, while the high inundation treatment received inundation twice daily to a depth of $5 \mathrm{~cm}$, with approximate inundation times of $4.5 \mathrm{~h}$ per tide cycle (Fig 1). Two nutrient availability levels were produced by growing half of plants in the soils amended with Osmocote Mini Prill 19-6-10 to a dosage of $7 \mu \mathrm{M} \mathrm{m}^{-2} \mathrm{~N}\left(47 \% \mathrm{NH}_{4} ; 52 \% \mathrm{NO}_{3}\right)$ and $0.2 \mu \mathrm{M} \mathrm{m}^{-2} \mathrm{P}$ and half in un-amended soils as controls. Three species combinations were planted: S. patens monocultures, D. spicata monocultures, and species mixtures. Position was randomized between tanks so that each tank contained a mixture of treatments, including a mixture of nutrient treatments. Over time, tank water remained un-enriched in nutrient levels (4-7 $\mu \mathrm{m} \mathrm{NH}_{4}$ and 2-7 $\mu \mathrm{m} \mathrm{PO}_{4}$ ). Median nutrient levels declined over time in both fertilized and unfertilized pots, although no significant changes over time were noted in 'control' or unplanted pots.

Plugs were planted in pots $10 \mathrm{~cm}$ in width, and $40 \mathrm{~cm}$ in length, to hold constant volume available for root growth. Bases were fitted with a mesh nylon screen, to allow water exchange. Brackish water (15\%) was generated using seawater inputs, a reverse osmosis system, and a static mixer to replicate the volume weighted average salinity for the Pettaquamscutt River Estuary, where plants were collected (Kelly and Moran 2002). All 
tanks received a rain treatment (in accordance with RI mean rainfall values) three to four times per week using water from roof rain collectors.

Plants were propagated under treatment conditions from 13 June to 25 September 2012 (103 days). On 22 June, 26 July, and 24 September, porewater samples were collected from a subset of pots (31) that had been outfitted with piezometers. A first subsample was obtained, filtered, and preserved (1:1) with a $0.22 \%$ solution of zinc acetate $\left(\mathrm{Zn}\left(\mathrm{O}_{2} \mathrm{CCH}_{3}\right)_{2}\right)$ for hydrogen sulfide analysis. Larger subsamples were similarly filtered and frozen for later nutrient analysis. Porewater samples were analyzed for hydrogen sulfide using a Genesys 2 spectrophotometer (Cline 1969; Strickland and Parsons 1972), and for nitrate plus nitrite, ammonium and phosphate using an Astoria Pacific A2 micro-segmented flow autoanalyzer (U.S. EPA methods 350.1, 353.2, and 365.2).

\section{Photosynthesis, growth and biomass analysis}

Shoot heights and density were measured on 11 June 2012, 31 Jul 2012, and 25 Sept 2012. To determine treatment effects on mixed species assemblages, changes in the relative abundance of individual shoots by species were calculated. At the experiment's conclusion, plant mass was harvested, rinsed, and dried to a constant weight at $60^{\circ} \mathrm{C}$ in a convection oven. Belowground biomass was measured for monocultures as the dry weight of belowground biomass retained by wet sieving, dried to constant weight. Root and rhizome material was separated to determine the ratio of root-supported tissue (shoots, rhizomes) to root biomass (RSB/RB ratio) (Morris et al., 2013). Dried aboveground plant tissue (shoots, stems, leaves) were subsampled, ground using a Wiley Mini Mill, and analyzed for total carbon and nitrogen using a Flash EA112 elemental analyzer.

As an indicator of photosynthetic rate, $\mathrm{CO}_{2}$ uptake was measured (on 19-21 June 2012, 3-9 July 2012, and 23-25 July 2012) using a flow-through infrared gas analyzer (IRGA 
model LCA4; ADC Bioscientific, UK). All $\mathrm{CO}_{2}$ uptake rates were normalized to area of plant tissue in the leaf chamber calculated through image analysis of digital photo macrographs taken during flux measurements. The excitation transfer efficiency of open photosystem II reaction centers was measured with a Plant Efficiency Analyzer (Hanzateck, UK) also on 21 June 2012, 3 July 2012, and 23 July 2012. Fluorescence measurements were made with $2 \mathrm{~s}$ of excitation light $\left(3,000 \square \mathrm{mol} \mathrm{m}^{-2} \mathrm{~s}^{-1}\right.$ of red light, peak at $\left.660 \mathrm{~nm}\right)$, on clusters of living leaves dark adapted for at least 20 minutes prior to measures. $\mathrm{F}_{\mathrm{O}}$ was calculated as the fluorescence value at $50 \mu$ s when all reaction centers of photosystem II were assumed open, and $\mathrm{F}_{\mathrm{M}}$, as the maximum fluorescence value, where it was assumed that the level of light excitation was high enough to close all the reaction centers. The maximum quantum efficiency was calculated as $\mathrm{F}_{\mathrm{V}} / \mathrm{F}_{\mathrm{M}}$, where $\mathrm{F}_{\mathrm{V}}=\mathrm{F}_{\mathrm{M}}-\mathrm{F}_{\mathrm{O}}$.

After plants were harvested, $\mathrm{CO}_{2}$ efflux measures were performed on intact soils using a Licor 8100 laser infrared analyzer outfitted with an opaque static chamber. Soil stems were plugged with silicone to minimize root and rhizome gasses to flux measures, and macro-organic matter (surface litter) was removed from the soil surface. This efflux incorporates root respiration and soil organic matter decomposition (Wigand et al., 2009). Measures of $\mathrm{CO}_{2}$ concentration were made every second for a period of three minutes, with the first $30 \mathrm{~s}$ of data discarded as a stabilization period. The increase in $\mathrm{CO}_{2}$ concentration within the chamber headspace was calculated using regression. Flux estimates were corrected for atmospheric pressure and temperature and scaled for area of soil enclosed by the chamber to yield the $\mathrm{CO}_{2}$ efflux rate:

$$
F l u x=\frac{d C O_{2}}{d t} \times \frac{P V}{A R T}
$$

where $d \mathrm{CO}_{2} / d t$ is the change in $\mathrm{CO}_{2}$ concentration over time, $P$ is the atmospheric pressure, $V$ is the volume of the headspace gas within the chamber, $A$ is the area of soil enclosed by the chamber, $R$ is the universal gas constant, and $T$ is the air temperature. Because soil $\mathrm{CO}_{2}$ flux 
rates were a linear function of soil temperature $\left(R^{2}=0.47 ; p<0.001\right)$ and ranged across more than $10^{\circ} \mathrm{C}$, flux values were normalized to a soil temperature at $25^{\circ} \mathrm{C}$ prior to data analysis.

\section{Plant distribution surveys}

To provide insight into the distribution of D. spicata and S. patens at field sites, surveys of plant presence were conducted at five southern New England tidal marshes during the summer of 2012 (Nag Marsh and Pond, 29 ha, $41.62^{\circ} \mathrm{N}, 71.32^{\circ} \mathrm{W}$; Mary Donovan Marsh, 24 ha, $41.55^{\circ} \mathrm{N}, 71.21^{\circ} \mathrm{W}$; Pettaquamscutt Cove, 17 ha. $41.44^{\circ} \mathrm{N}, 71.46^{\circ} \mathrm{W}$; Hundred Acre Cove, 6 ha, $41.77^{\circ} \mathrm{N}, 71.31^{\circ} \mathrm{W}$; Brushneck Cove, 2 ha, $\left.41.70^{\circ} \mathrm{N}, 71.42^{\circ} \mathrm{W}\right)$. At each site, parallel transects between the marsh upland and shore were run $5 \mathrm{~m}$ apart, with sampling points located every $5 \mathrm{~m}$. At each marsh, a total of 115-400 points were sampled, with larger marshes having more sampled points.

To relate plant distributions to inundation, elevation was measured at each sampling point. Topographic surveys of salt marsh elevations were performed relative to 2-3 temporary benchmarks established at each marsh site, where positions were established using static PPK (post-processed kinematic) GPS surveys. Elevations are reported relative to the NAVD88 datum. For comparison, mean sea level (MSL) in Narragansett Bay for the 1983 to 2001 tidal datum epoch is $-0.09 \mathrm{~m}$ NAVD88 and mean high water (MHW) is $0.48 \mathrm{~m}$ NAVD88 (for the Newport, RI tide station; for the Providence tide station, MSL=-0.07m NAVD88; MHW= 0.65m NAVD88; NOAA 2015).

Nutrient inputs at sites were characterized using porewater ammonium values. Porewater was collected from a depth of $20 \mathrm{~cm}$ collected using a porewater "sipper" or piezometer (e.g., Watson et al., 2014) at field sites over the course of the growing season $(2011 / 2)$. Porewater ammonium was used as an indicator of nutrient availability for field and experimental units. Porewater was analyzed for ammonium and phosphate using an Astoria 
Pacific A2 micro-segmented flow autoanalyzer (U.S. EPA methods 350.1 and 365.2). Marsh elevation and nutrient availability were characterized using the median value of elevation (of 115-400 values) and porewater ammonium (of 50-90 values) at each site.

\section{Data analysis}

As some monoculture pots ended up mixtures, we reclassified three $S$. patens and one D. spicata pot as mixtures. Nitrogen concentration was calculated for shoots as nitrogen weight per unit dry weight. Two-way ANOVAs were carried out to examine impacts of inundation and nutrient availability on plant growth and photosynthesis. Analysis was performed on logarithmic transformations of some variables to meet variance and normality requirements. Where a significant interaction term was identified, a simple main effects follow up ANOVA was performed. To assess change in proportion of S. patens shoots in mixed pots, the exact form of the Wilcoxon signed rank test was used (Helsel and Hirsch 2002). A two-way analysis of variance was further used to examine $\mathrm{N}$ concentrations in mixed and monoculture pots, and inundation and fertilization treatment combinations were included as blocks. Linear regression was used to relate plant growth patterns measured at field sites with inundation and nutrient availability. Statistical analyses were performed using SPSS Statistics (version 22, IBM, Armonk, NY, USA). 


\section{RESULTS}

\section{Growth \& biomass}

Plant growth response variables co-varied with inundation and nutrient availability (Fig. 2; Supplementary Material). For fertilized S. patens plants, aboveground biomass was reduced by $70 \%$ and tiller density by $54 \%$ by high inundation. For the high inundation treatment, fertilization reduced aboveground biomass by $5.5 \%$ and tiller density by $16 \%$, while for the low inundation treatment, fertilization increased aboveground biomass by $103 \%$ and tiller density by $30 \%$. For fertilized $S$. patens plants, the RSB/RB ratio was reduced $56 \%$ by high inundation, and for the low inundation treatment, fertilization increased the RSB/RB ratio by $30 \%$.

Among fertilized D. spicata plants, high inundation reduced aboveground biomass by $62 \%$, tiller density by $41 \%$, rhizome biomass by $65 \%$, and the RSB/RB ratio by $75 \%$. Nutrient availability significantly impacted aboveground biomass, tiller height and density, rhizome biomass, and the RSB/RB ratio. Fertilization increased D. spicata aboveground biomass by $21 \%$, tiller height by $19 \%$, and tiller density by $63 \%$. For the low inundation treatment, fertilization increased rhizome biomass by $60 \%$ and the RSB/RB ratio by $129 \%$. Similar to $S$. patens, a significant interaction was found for treatment combinations such that D. spicata growth was increased by fertilization more under less inundated conditions. In contrast to $S$. patens, however, nutrient additions had beneficial impacts to a wider range of plant growth response variables.

\section{Bi-species mixtures}

Growth of mixtures under low and high nutrient availability and inundation treatment combinations revealed changes in the proportion of S. patens. Spartina patens expanded at the expense of D. spicata, when grown in mixtures under low nutrient availability (by $7.5 \%$ ) 
and well drained conditions, but declined relative to D. spicata when grown under higher nutrient availability and more inundated conditions (by 6.1\%) (Fig. 3). Wilcoxon signed rank tests suggested a statistically significant expansion for $S$. patens $(W+=19, \mathrm{p}<0.05)$ grown under low inundation, unfertilized conditions, and a statistically significant decline $(W+=1$, $\mathrm{p}<0.05)$ for $S$. patens grown under high inundation, fertilized conditions. The other two treatments (high inundation, fertilized and low inundation, unfertilized) saw small but not significant declines in proportion of $S$. patens shoots (1.8 and $1.7 \%$, respectively).

\section{Photosynthesis}

Variables associated with plant photosynthesis were similarly found to co-vary with inundation and nutrient availability (Fig. 4, Supplementary Material). For S. patens, high inundation was associated with a reduction in soil $\mathrm{CO} 2$ efflux (by $60 \%$ ), and nutrient availability was associated with a $19 \%$ decline in leaf $\mathrm{CO}_{2}$ uptake (an indicator of photosynthetic rate). A significant interaction was found between the inundation and nutrient availability treatments, such that high nutrient loads and daily inundation had a combined detrimental impact on photosynthetic efficiency. For fertilized pots, high inundation was associated with a $5.3 \%$ reduction in photosynthetic efficiency for S. patens, and for high inundation, fertilizer addition was associated with a $3.8 \%$ reduction in photosynthetic efficiency.

For D. spicata, high inundation was associated with reduced photosynthetic efficiency (by $2.2 \%$ ) and soil $\mathrm{CO}_{2}$ efflux rates (by $14 \%$ ), and higher nutrient availability was associated with increased soil $\mathrm{CO}_{2}$ efflux (by $87 \%$ ). A significant interaction was found between inundation and nutrient availability such that fertilization resulted in greater $\mathrm{CO}_{2}$ uptake under daily inundation, but lower $\mathrm{CO}_{2}$ uptake under aerated conditions. 


\section{Soil chemistry}

Measures of porewater sulfide and ammonium concentrations indicated higher sulfide concentrations for pots exposed to high inundation, and higher porewater ammonium concentrations for fertilized pots (Fig. 5). For pots exposed to daily inundation, porewater sulfide concentrations ranged from 0 to $2500 \mu \mathrm{M}$, with a median value of $210 \mu \mathrm{M}$. For pots grown under low inundation, porewater sulfide concentrations ranged from 0 to $11 \mu \mathrm{M}$, with a median value of $0 \mu \mathrm{M}$. For pots that received no added fertilizer, porewater ammonium concentrations ranged from 9-701 $\mu \mathrm{M}$, with a median value of $51 \mu \mathrm{M}$. For pots that received added fertilizer, ammonium concentrations ranged from 7-4600 $\mu \mathrm{M}$, with a median value of $188 \mu \mathrm{M}$.

A comparison of laboratory porewater with porewater from field sites suggests that the porewater ammonium concentrations found in our laboratory experiments are similar to some field conditions. Of the five sites analyzed, two field sites were similar to low nutrient availability laboratory conditions (Narrow River: median= 40, range $=4-201 \mu \mathrm{M} \mathrm{NH}_{4}{ }^{+}$; Hundred Acre Cove: median= 21, range $=8-227 \mu \mathrm{M} \mathrm{NH}_{4}{ }^{+}$), while other field sites had as high or higher nutrient availability than replicated by the laboratory experiment (Brushneck Cove: median $=130$, range $=19-650 \mu \mathrm{M} \mathrm{NH}_{4}{ }^{+}, \mathrm{Nag}$ Marsh: median $=261$, range $=14-2000$ $\mu \mathrm{M} \mathrm{NH}_{4}{ }^{+}$, Mary Donovan: median $=675$, range $\left.=12-14,500 \mu \mathrm{M} \mathrm{NH}_{4}{ }^{+}\right)$.

Contrasting porewater sulfide concentrations at field sites with laboratory inundation treatments suggests that field sites tended to have more variable porewater sulfide concentrations than found in our laboratory experiment. At field sites, low elevation porewater sulfide concentrations ranged from 0 to $13,500 \mu \mathrm{M} \mathrm{H}_{2} \mathrm{~S}$, with a median of $710 \mu \mathrm{M}$, in comparison with the laboratory experiment, which had a range of 0 to $2500 \mu \mathrm{M}$, with a median value of $210 \mu \mathrm{M}$ for the low elevation / high inundation treatment. Field samples 
collected from higher elevations had porewater sulfide concentrations ranging from 0 to 2400 $\mu \mathrm{M}$, with a median value of $0.691 \mu \mathrm{M}$, while under laboratory conditions, low inundation / high elevation pots had porewater sulfide concentrations ranging from to 0 to $11 \mu \mathrm{M}$.

\section{Tissue nitrogen}

A comparison of shoot $\mathrm{N}$ concentration for $S$. patens and D. spicata grown as monocultures and in mixtures suggests that D. spicata had a superior ability to assimilate available N (Fig. 6). While only modest differences were apparent between the plant species when they were grown as monocultures, when plants were grown as mixtures, shoot $\mathrm{N}$ concentration were greater for $D$. spicata than for $S$. patens. These results are supported by ANOVA models that reveal significant main effects of species $(F=8.746, p=0.004)$ and mixture $(F=5.799, p=0.018)$ on shoot $\mathrm{N}$ concentration.

\section{Field Surveys}

Results of our comparative surveys revealed that both nutrient availability and inundation appear to structure the distribution of $D$. spicata and $S$. patens in southern New England coastal wetlands (Fig. 7). Field data suggests that D. spicata and S. patens are restricted to the higher elevation portion of marshes (Fig. 7A-C), and marshes that sit higher in elevation support a greater abundance of $D$. spicata and S. patens (Fig. 7D). In addition, D. spicata was found to be more common in marshes with higher nutrient availability, as measured through porewater ammonium concentrations (Fig. 7E), while S. patens was found to be less common (Fig. 7F).

\section{DISCUSSION}

The results of the present study suggest that both inundation and nutrient additions 
alter growth, photosynthesis, and competitive interactions for D. spicata and S. patens. While previous studies have shown that $D$. spicata is competitively dominant under conditions of high nutrient availability (Emery et al., 2001; Hunter et al., 2008), and that the response of $S$. patens to nutrient additions is mediated by drainage (Whigham and Nusser 1990; Langley et al., 2013), the present study helps clarify the inconsistent response of high marsh taxa to nutrient additions in field experiments (e.g., Anisfeld and Hill 2012; Deegan et al., 2013). For S. patens, added nutrients have a beneficial effect on growth in well-drained soils, but a potentially negative effect on growth, photosynthesis, and competitive interactions when grown under high inundation levels. Added nutrients resulted in a more symmetric response for D. spicata, where nutrient additions typically enhanced growth regardless of inundation level. A comparison with field data further suggests that $S$. patens presence is restricted to higher elevation and lower nutrient availability sites. By highlighting the different responses of $S$. patens and D. spicata to the interactive effects of nutrient additions across elevation treatments, our results provide new perspectives on coastal anthropogenic impacts to Northeastern U.S. marsh plant distribution shifts.

\section{Spartina patens}

Spartina patens growth in our factorial experiment was influenced by nutrient and flooding treatments such that nutrient additions subsidized growth (above and belowground biomass and tiller density) under well-drained conditions, but under flooded conditions neutral or negative effects were noted for photosynthesis and tiller density. Coupled with observations of competitive dominance under well drained, low nutrient availability conditions and declines where nutrient additions were coupled with daily flooding, these results suggest that $S$. patens may respond positively or negatively to nutrient additions, depending on factors relating to elevation or flooding. These results clarify previous reports 
(Valiela et al., 1976; Pennings et al., 2005; Wigand et al., 2009), which identified contradictory responses of $S$. patens to nutrient additions in the field. Our results are also in agreement with previous studies that specifically considered interactions with drainage or elevation (Whigham and Nusser 1990; Levine et al., 1998; Emery et al., 2001).

However, if tidal marsh plant species are nutrient limited in New England coastal wetlands (Valiela and Teal 1979), why would added nutrients adversely affect $S$. patens when grown under high flooding levels? We postulate that three potential interactions between root and soil conditions might explain this phenomenon.

In intertidal and subtidal environments, nutrient inputs have been associated with accumulations of the phytotoxin sulfide (McHugh and Dighton 2004; Watson et al., 2014). Labile organic carbon inputs associated with eutrophic conditions may fuel the paired process of sulfate reduction and organic matter mineralization that occurs under anaerobic conditions (Howarth and Teal 1979). Where nutrient additions fuel sulfate reduction, plants will respond negatively when sulfide levels become toxic. While this explanation may explain some negative effects of eutrophication on salt marshes (e.g., Darby and Turner 2008), in the present study, we did not find elevated sulfide concentrations in fertilized vs. control plots (Fig. 5). We surmise that the experimental application of nutrients to marsh soils is fundamentally different than nutrients delivered via the water column where macroalgae and phytoplankton growth (i.e. labile carbon inputs) co-occur with elevated nutrient levels.

Another potential explanation for reduced Spartina patens growth under elevated flooding may involve arenchyma, the gas spaces in plant tissues that allow for gas exchange and aeration. In graminoid crop plants (rice, maize, wheat), studies of nutrient levels have found that low nutrient conditions can stimulate the formation of arenchyma (e.g. Drew et al., 2000; He et al., 1992; Fan et al., 2003). If nutrient levels provide a primary control on the formation of cortical arenchmya in $S$. patens, high nutrient availability may inhibit 
arenchyma formation, even though its development would be beneficial for maintaining aerobic respiration under flooded conditions.

A final potential explanation of negative effects of nutrient additions on $S$. patens may include shifts in its relationship with fungal symbionts. Like most terrestrial plants, wetland species (Burke et al., 2002; Bohrer et al., 2004), form associations with arbuscular mycorrhizal fungi (AMF) root symbionts. Associations with AMF increase access to nutrients, which can alter growth rates and plant community interactions (Bever et al., 2001). In this study, nutrient additions had an asymmetric affect on $S$. patens, with positive impacts under well-drained conditions, and negligible or negative impacts under flooded conditions. Shifts in flooding and nutrient availability may have shifted the plant-AMF association from mutualistic to parasitic, as has been noted in previous nutrient addition studies (Daleo et al., 2008; Kivlin et al., 2013). Additional support for this interpretation comes from previous studies that have noted AMF colonization focused in arenchymous tissue in salt marsh plants (Brown and Bledsoe 1996).

\section{Distichlis spicata}

In contrast with $S$. patens, D. spicata responded positively to nutrient additions through increased cover, biomass, and plant community composition (Levine et al., 1998; Pennings et al., 2005; Hunter et al., 2008), demonstrating that D. spicata is able to exploit elevated nutrient levels to a greater degree than $S$. patens. Our field survey results provide further evidence that $D$. spicata responds positively to nutrient additions: a strong positive relationship was found between $D$. spicata growing in monoculture and site $\mathrm{N}$ availability (Fig. 7). These results are in agreement with previous studies. For example, in a long-term nutrient addition experiment ( $\sim 35 \mathrm{y})$ on Cape Cod, D. spicata has slowly displaced other marsh taxa present in heavy fertilizer application plots (Fox et al., 2012), and D. spicata 
predominates in Pacific Coast marshes where cattle grazing occurs on adjacent lands (Traut 2005).

Of particular note were the extremely high $D$. spicata belowground biomass values $\left(\sim 10,000 \mathrm{~g} \mathrm{~m}^{-2}\right)$ found in our greenhouse study. Where D. spicata invades in response to nutrient enrichments (Rogers et al., 1998; Fox et al., 2012), it appears capable of raising marsh elevation through enhanced belowground production and reduced rates of decomposition in comparison with Spartina alterniflora (Valiela et al., 1985; Valiela 2015). Our experimental results support previous interpretations of elevation gains linked to fertilization and the competitive dominance of $D$. spicata.

\section{Species pairings}

Where grown as mixtures, $S$. patens expanded relative to D. spicata under conditions of low inundation and low nutrient availability, but declined relative to D. spicata when grown under high nutrient levels and high inundation. These results suggest contrasting - and synergistic - responses of high marsh plant species to anthropogenic impacts. Spartina patens appears most vulnerable to loss where increased inundation coincides with nutrient subsidies from cultural eutrophication, while $D$. spicata is favored by high nutrient availability. These results are supported in part by field data: D. spicata grows in mixtures with $S$. patens under conditions of low N availability, but as a monoculture under high $\mathrm{N}$ availability. In addition, overall abundance of $S$. patens is a function of $\mathrm{N}$ availability, with lower $\mathrm{N}$ availability associated with greater abundance of $S$. patens.

Additional differences were noted in $\mathrm{N}$ concentration between plants grown as monocultures and as mixtures. In both monocultures and mixture pots, $\mathrm{N}$ concentration was higher in fertilized plots. With one exception, $\mathrm{N}$ concentration did not differ between species for plants grown as monocultures. For pairings, $\mathrm{N}$ concentration was significantly higher for 
$D$. spicata than for $S$. patens. This comparison suggests that $D$. spicata presence alters the uptake of N by S. patens. This shift in N density occurred regardless of whether $S$. patens was competitively dominant or subordinate, in accordance with treatment combinations.

\section{Growth responses and long-term marsh survival}

Growth responses to nutrient additions and interactions with inundation are of interest to the broader estuarine science and management community (Anisfeld and Hill 2012), as recent studies suggest marsh loss in the New England region is accelerating (Smith 2009; Watson et al., 2014). Nutrient additions are suspected to have both positive and negative effects on plant growth and organic matter accumulation in wetlands (e.g. Darby and Turner 2008; Wigand et al., 2009; Deegan et al., 2012; Morris et al., 2013; Watson et al., 2014). Of particular importance to long-term marsh survival are effects on stem density and belowground production. Under conditions of adequate nutrition, graminoids may allocate more resources towards vegetative reproduction through increased shoot density (Traut 2005); which has the benefit of increasing sediment-trapping efficiency (Morris et al., 2002). Also crucial for long-term marsh survival is belowground productivity, particularly for rhizomes, which contribute to formation of marsh peat (Morris et al., 2013). Where sediment inputs are low and declining, (Roman et al., 2000; Weston 2014), marshes build in elevation primarily through in-situ plant growth, making belowground production a particularly crucial process in an era of rapidly rising sea levels.

In this study, we found that nutrient inputs resulted in similar biomass partitioning responses for D. spicata and S. patens. Fertilization increased tiller density and rhizome production in both species, but only for the low inundation treatment. We therefore conclude that marsh elevation may play an important role in the response of coastal marsh to nutrient additions, as has been found in other recent reports (Langley et al. 2013; Watson et al. 2014). 
Where marsh elevation is low and daily flooding occurs, both rhizome production and tiller density are unaltered by nutrient inputs. However, where marsh elevation is high, additional nutrients may provide positive benefits for marsh aggradation through enhanced sediment trapping and organic matter accumulation.

\section{Vegetation change}

While early and mid twentieth century reports characterize $S$. patens as the most common plant species for New England coastal wetlands, recent studies have noted reduced abundance of $S$. patens and other species found in the upper marsh (Warren and Niering 1993; Roman et al., 1997; Donnelly and Bertness 2001; Smith 2009; Smith et al., 2012; Smith 2015; K Raposa, NBNERR, Prudence Island, RI, unpubl. res.). Potential explanatory factors include increased flooding associated with accelerated sea level rise and increased nutrient availability associated with coastal development (Warren and Niering 1993; Wigand et al., 2003). This shift is of concern for the coastal management community, as the disappearance of high marsh habitat due to increased flooding bodes poorly for the long-term survival of coastal marshes, and also may have negative consequences to coastal marsh nesting sparrows (Elphick et al., In Press). Results of our greenhouse experiment support the hypothesis that the disappearance of $S$. patens may be driven by increased flooding and high nutrient loads, in combination. Enhancement strategies currently are being enacted in the region to facilitate re-colonization of marshes by S. patens. These strategies include thin layer deposition to build marsh elevations and lowering of marsh groundwater tables through drainage enhancements. The results of our study also suggest that remediation of high coastal nutrient loads may be beneficial for $S$. patens survival, although to be effective such efforts such be focused where nutrient levels are highest. 


\section{ACKNOWLEDGEMENTS}

We acknowledge K. Kelly for maintaining the flow-through seawater system, R. Ahlgren for arranging the reverse osmosis system, and the U.S. Fish and Wildlife Service, the Barrington Land Trust, the City of Warwick, and the Nature Conservancy for access to field sites. The Narragansett Bay National Estuarine Research Reserve provided access to the field sites on Prudence Island, loans of field equipment and logistical and technical support, and we would like to specifically recognize K. Raposa, D. Durant, and R. Weber for their contributions. A. Hanson, R. Johnson, A. Oczkowski, C. Esch, M. Chintala, J. Bishop, and N. Angelo provided field and laboratory assistance. R. McKinney, G. Thursby, and R. Johnson provided helpful input on an earlier version of this manuscript. This report is tracking number ORD-003241 of the U.S. EPA's Office of Research and Development, National Health and Environmental Effects Research Laboratory, Atlantic Ecology Division. Although the information in this document has been funded by the U.S. Environmental Protection Agency, it does not necessarily reflect the views of the Agency and no official endorsement should be inferred. Mention of trade names or commercial products does not constitute endorsement or recommendation for use. 


\section{REFERENCES}

Anisfeld, S.C., and Hill, T.D. 2012. Fertilization effects on elevation change and belowground carbon balance in a Long Island Sound tidal marsh. Estuaries Coasts 35(1): 201-211. doi:10.1007/s12237-011-9440-4.

Bertness, M.D. 1991. Zonation of Spartina patens and Spartina alterniflora in New England salt marsh. Ecology 72(1): 138-148. doi:10.2307/1938909.

Bertness, M.D., Ewanchuk, P.J., and Silliman, B.R. 2002. Anthropogenic modification of New England salt marsh landscapes. Proc. Natl. Acad. Sci. U.S.A. 99(3): 1395-1398. doi:10.1073/pnas.022447299.

Bever, J.D., Schultz, P.A., Pringle, A., and Morton, J.B. 2001. Arbuscular mycorrhizal fungi: more diverse than meets the eye, and the ecological tale of why. BioScience 51(11): 923-932. doi:10.1641/0006-3568(2001)051[0923:AMFMDT]2.0.C.

Bohrer, K.E., Friese, C.F., and Amon, J.P. 2004. Seasonal dynamics of arbuscular mycorrhizal fungi in differing wetland habitats. Mycorrhiza 14(5): 329-337. doi:10.1007/s00572-004-0292-7.

Broome, S.W., Mendelssohn, I.A., and McKee, K.L. 1995. Relative growth of Spartina patens (Ait.) Muhl. and Scirpus olneyi Gray occurring in a mixed stand as affected by salinity and flooding depth. Wetlands 15(1): 20-30. doi:10.1007/BF03160676.

Brown, A.M., and Bledsoe, C. 1996. Spatial and temporal dynamics of mycorrhizas in Jaumea carnosa, a tidal saltmarsh halophyte. J. Ecol. 84(5): 703-715. doi: $10.2307 / 2261333$

Burdick, D.M., and Mendelssohn, I.A. 1990. Relationship between anatomical and metabolic responses to soil waterlogging in the coastal grass Spartina patens. J. Exp. Bot. 41(2): 223-228. doi:10.1093/jxb/41.2.223. 
Burke, D.J., Hamerlynck, E.P., and Hahn, D. 2002. Interactions among plant species and microorganisms in salt marsh sediments. Appl. Environ. Microbiol. 68(3): 1157-1164. doi:10.1128/AEM.68.3.1157-1164.2002.

Butler, P. 1959. Palynological studies of the Barnstable Marsh, Cape Cod, Massachusetts. Ecology 40(4): 735-737. doi:10.2307/1929835.

Chapman, V.J. 1940. Succession on the New England salt marshes. Ecology 21(4): 279-282.

Civco, D.L., Kennard, W.C., and Lefor, M.W. 1986. Changes in Connecticut salt-marsh vegetation as revealed by historical aerial photographs and computer-assisted cartographics. Environ. Manage. 10(2): 229-239. doi: 10.1007/BF01867361.

Cline, J.D. 1969. Spectrophotometric determination of hydrogen sulfide in natural waters. Limnol. Oceanogr.14(3): 454-458. doi:10.4319/1o.1969.14.3.0454.

Daleo, P., Alberti, J., Canepuccia, A. Escapa, M., Funjul, E., Silliman, B.R., Bertness, M.D., and Iribarne, O. 2008. Mycorrhizal fungi determine salt $\square$ marsh plant zonation depending on nutrient supply. J. Ecol. 96(3): 431-437. doi:10.1111/j.13652745.2007.01349.x.

Darby, F.A., and Turner, R.E. 2008. Effects of eutrophication on salt marsh root and rhizome biomass accumulation. Mar. Ecol.: Prog. Ser. 363: 63-70. doi: $10.3354 / \operatorname{meps} 07423$.

Deegan, L.A., Johnson, D.S., Warren, R.S., Peterson, B.J., Fleeger, J.W., Fagherazzi, S., Wollheim, W.M. 2012. Coastal eutrophication as a driver of salt marsh loss. Nature 490(7420): 388-392. doi:10.1038/nature11533.

Donnelly, J.P., and Bertness, M.D. 2001. Rapid shoreward encroachment of salt marsh cordgrass in response to accelerated sea-level rise. Proc. Natl. Acad. Sci. U.S.A. 98(25): 14218-14223. doi: 10.1073/pnas.251209298. 
Drew, M.C., He, C.J., and Morgan, P.W. 2000. Programmed cell death and aerenchyma formation in roots. Trends Plant. Sci. 5(3): 123-127. doi:10.1016/S1360$1385(00) 01570-3$

Elphick, C.S., Meiman, S., and Rubega, M.A. In Press. Tidal-flow restoration provides little nesting habitat for a globally vulnerable saltmarsh bird species. Restor. Ecol. doi:10.1111/rec.12194.

Emery, N.C., Ewanchuk, P.J., and Bertness, M.D. 2001. Competition and salt-marsh plant zonation: stress tolerators may be dominant competitors. Ecology 82(9): 2471-2485. doi:10.1890/0012-9658(2001)082[2471:CASMPZ]2.0.CO;2.

Ezer, T., Atkinson, L.P., Corlett, W.B., and Blanco, J.L. 2013. Gulf Stream's induced sea level rise and variability along the U.S. mid $\square$ Atlantic coast. J. Geophys. Res.: Oceans 118(2): 685-697. doi:10.1002/jgrc.20091.

Fan, M., Zhu, J., Richards, C., Brown, K.M., and Lynch, J.P. 2003. Physiological roles for aerenchyma in phosphorus-stressed roots. Funct. Plant Biol. 30(5): 493-506.

Foret, J.D. 2001. Nutrient limitation of tidal marshes on the Chenier Plain, Louisiana. Ph.D. thesis, University of Louisiana at Lafayette, USA.

Fox, L., Valiela, I., and Kinney, E.L. 2012. Vegetation cover and elevation in long-term experimental nutrient-enrichment plots in Great Sippewissett Salt Marsh, Cape Cod, Massachusetts: implications for eutrophication and sea level rise. Estuaries Coasts 35(2): 445-458. doi:10.1007/s12237-012-9479-x.

Gleason, M.L., and Zieman, J.C. 1981. Influence of tidal inundation on internal oxygen supply of Spartina alterniflora and Spartina patens. Estuarine, Coastal Shelf Sci. 13(1): 47-57. doi:10.1016/S0302-3524(81)80104-1.

He, C.J., Morgan, P.W., and Drew, M.C. 1992. Enhanced sensitivity to ethylene in nitrogenor phosphate-starved roots of Zea mays L. during aerenchyma formation. Plant 
Physiol. 98(1): 137-142. doi:10.1104/pp.81.1.137.

Helsel, D.R., and Hirsch, R.M. 2002. Statistical methods in water resources. U.S. Geological Survey, Reston, Virginia, USA.

Howarth, R.W., and Teal, J.M. 1979. Sulfate reduction in a New England salt marsh. Limnol. Oceanogr. 24(6): 999-1013. doi:10.4319/1o.1979.24.6.0999.

Hunter, A., Morris, N.M.B., Lafabrie, C., and Cebrian, J. 2008. Effects of nutrient enrichment on Distichlis spicata and Salicornia bigelovii in a marsh salt pan. Wetlands 28(3): 760-775. doi:10.1672/06-149.1.

Kelly, R.P., and Moran, S.B. 2002. Seasonal changes in groundwater input to a well-mixed estuary estimated using radium isotopes and implications for coastal nutrient budgets. Limnol. Oceanogr. 47(6): 1796-1807. doi:10.4319/1o.2002.47.6.1796.

Kennish, M.J. 2001. Coastal salt marsh systems in the US: a review of anthropogenic impacts. J. Coastal Res. 17(3): 731-748.

Kivlin, S.N., Emery, S.M., and Rudgers, J.A. 2013. Fungal symbionts alter plant responses to global change. Am. J. Bot. 100(7): 1445-1457. doi:10.3732/ajb.1200558

Knight, J.B. 1934. A salt marsh study. Am. J. Sci. 28(165): 161-181. doi:10.2475/ajs.s528.165.161.

Kopp, R.E. 2013. Does the mid $\square$ Atlantic United States sea level acceleration hot spot reflect ocean dynamic variability? Geophys. Res. Lett. 40(15): 3981-3985. doi: 10.1002/grl.50781.

Langley, A.J., Mozder, T.J., Shepard, K.A., Hagerty, S.B., and Megonigal, J.P. 2013. Tidal marsh plant responses to elevated $\mathrm{CO}_{2}$, nitrogen fertilization, and sea level rise. Glob. Change Biol. 19(5): 1495-1503. doi:10.1111/gcb.12147.

Levine, J.M., Brewer, J.S., and Bertness, M.D. 1998. Nutrients, competition and plant zonation in a New England salt marsh. J. Ecol. 86(2): 285-292. 
McHugh, T.G., and Dighton, J. 2004. Influence of mycorrhizal inoculation, inundation period, salinity, and phosphorous availability on the growth of two salt marsh grasses, Spartina alterniflora Lois. and Spartina cynosuroides (L.) Roth., in nursery systems. Restor. Ecol. 12(4): 533-545. doi:10.1111/j.1061-2971.2004.03109.x.

Merino, J.H., Huval, D., and Nyman, A.J. 2010. Implication of nutrient and salinity interaction on the productivity of Spartina patens. Wetlands Ecol. Manage. 18(2): 111-117. doi:10.1007/s11273-008-9124-4.

Millennium Ecosystem Assessment. 2005. Ecosystems and human well-being: wetlands and water synthesis. World Resources Institute, Washington, D.C.

Miller, W.R., and Egler, F.E. 1950. Vegetation of the Wequetequock-Pawcatuck tidalmarshes, Connecticut. Ecol. Monogr. 20(2): 143-172. doi:10.2307/1943548.

Morris, J.T., Sundareshwar, P.V., Nietch, C.T., Kjerfve, B., and Cahoon, D.R. 2002. Responses of coastal wetlands to rising sea level. Ecology 83(10): 2869-2877. doi:10.1890/0012-9658(2002)083[2869:ROCWTR]2.0.CO;2.

Morris, J.T., Shaffer, G.P., and Nyman, J.A. 2013. Brinson Review: Perspectives on the influence of nutrients on the sustainability of coastal wetlands. Wetlands 33(6): 975988. doi:10.1007/s13157-013-0480-3.

National Oceanic and Atmospheric Administration (NOAA). 2015. Tide station datums. http://tidesandcurrents.noaa.gov. Accessed on 25 May 2015.

Niering, W.A., and Warren, R.S. 1980. Vegetation patterns and processes in New England salt marshes. BioScience 30(5): 301-307. doi:10.2307/1307853.

Nixon, S.W. 1982. The ecology of New England high salt marshes: a community profile. No. FWS/OBS-81/55. National Coastal Ecosystems Team and the University of Rhode Island Graduate School of Oceanography, Washington, D.C. and Kingston, RI, USA. O'Connor, J.S., and Terry, O.W. 1972. The marine wetlands of Nassau and Suffolk Counties, 
New York. Marine Sciences Research Center and the Nassau-Suffolk Regional Planning Board, State University of New York, Stony Brook, NY, USA.

Pennings, S.C., Clark, C.M., Cleland, E.E., Collins, S.L., Gough, L., Gross, K.L., Milchunas, D.G., and Sunding K.N. 2005. Do individual plant species show predictable responses to nitrogen addition across multiple experiments? Oikos 110(3): 547-555. doi:10.1111/j.0030-1299.2005.13792.x.

Pezeshki, S.R., Matthews, S.W., and Delaune, R.D. 1991. Root cortex structure and metabolic responses of Spartina patens to soil redox conditions. Environ. Exp. Bot. 31(1): 91-97. doi:10.1016/0098-8472(91)90011-C.

Reed, D.J. 1995. The response of coastal marshes to sea $\square$ level rise: survival or submergence?

Earth Surf. Processes Landforms 20: 39-48.

Rogers, J., Harris, J., and Valiela, I. 1998. Interaction of nitrogen supply, sea level rise, and elevation on species form and composition of salt marsh plants. Biological Bulletin 195(1): 235-237. doi:10.1002/esp.3290200105.

Roman, C.T., Peck, J.A., Allen, J.R., King, J.W., and Appleby, P.G. 1997. Accretion of a New England (USA) salt marsh in response to inlet migration, storms, and sea-level rise. Estuarine, Coastal Shelf Sci. 45(6): 717-727. doi:10.1006/ecss.1997.0236.

Roman, C.T., Joworski, N., Short, F.T., Findlay, S., and Warren, R.S. 2000. Estuaries of the northeastern United States: habitat and land use signatures. Estuaries 23(6): 743-764. doi: $10.2307 / 1352997$.

Sallenger, A.H., Jr, Doran, K.S., and Howd, P.A. 2012. Hotspot of accelerated sea-level rise on the Atlantic coast of North America. Nat. Clim. Change 2(12): 884-888. doi:10.1038/nclimate1597.

Silander, J.A., and Antonovics, J. 1979. The genetic basis of the ecological amplitude of 
Spartina patens. I. Morphometric and physiological traits. Evolution 33(4): 11141127. doi:10.2307/2407471.

Smith, S.M. 2009. Multi-decadal changes in salt marshes of Cape Cod, MA: photographic analyses of vegetation loss, species shifts, and geomorphic change. Northeast. Nat. 16(2): 183-208. doi:10.1656/045.016.0203.

Smith, S.M. 2015. Vegetation change in salt marshes of Cape Cod National Seashore (Massachusetts, USA) between 1984 and 2013. Wetlands 35(1): 127-136. doi: 10.1007/s13157-014-0601-7.

Smith, S.M., Medeiros, K.C., and Tyrrell, M.C. 2012. Hydrology, herbivory, and the decline of Spartina patens (Aiton) Muhl. in outer Cape Cod salt marshes (Massachusetts, USA). J. Coastal Res. 28(3): 602-612. doi:10.2112/JCOASTRES-D-10-00175.1

Spalding, E.A, and Hester, M.W. 2007. Interactive effects of hydrology and salinity on oligohaline plant species productivity: implications of relative sea-level rise. Estuaries Coasts 30(2): 214-225. doi:10.1007/BF02700165

Strickland, J.D.H., and Parsons, T.R. 1972. A practical handbook of seawater analysis. Fisheries Research Board of Canada, Ottawa.

Sweet, W.V., and Zervas, C. 2011. Cool-season sea level anomalies and storm surges along the U.S. East Coast: climatology and comparison with the 2009/10 El Niño. Mon. Weather Rev. 139(7): 2290-2299. doi:10.1175/MWR-D-10-05043.1.

Taylor, N. 1938. A preliminary report on the salt marsh vegetation of Long Island, New York. Bull. N. Y. State Museum 316: 21-84.

Traut, B.H. 2005. The role of coastal ecotones: a case study of the salt marsh/upland transition zone in California. J. Ecol. 93(2): 279-290. doi: 10.1111/j.13652745.2005.00969.x.

Valiela, I. 2015. The Great Sippewissett salt marsh plots—-some history, highlights, and 
contrails from a long-term study. Estuaries and Coasts 38(4): 1099-1120 doi:10.1007/s12237-015-9976-9.

Valiela, I., Teal, J.M., and Persson, N.Y. 1976. Production and dynamics of experimentally enriched salt marsh vegetation: belowground biomass. Limnology and Oceanography 21(2): 245-252. doi:10.4319/1o.1976.21.2.0245.

Valiela, I., Teal, J.M., Allen, S.D., Van Etten, R., Goehringer, D., and Volksmann, S. 1985. Decomposition in salt marsh ecosystems: the phases and major factors affecting disappearance of above-ground organic matter. J. Exp. Mar. Biol. Ecol. 89(1): 29-54.

Valiela, I., and Teal, J.M. 1979. The nitrogen budget of a salt marsh ecosystem. Nature 280: 652-656. doi:10.1038/280652a0

Warren, R.S., and Niering, W.A. 1993. Vegetation change on a northeast tidal marsh: interaction of sea-level rise and marsh accretion. Ecology 74(1): 96-103. doi:10.2307/1939504.

Watson, E.B., Oczkowski, A.J., Wigand, C., Hanson, A.R., Davey, E.W., Crosby, S.C., Johnson, R.L., and Andrews, H.M. 2014. Nutrient enrichment and precipitation changes do not enhance resiliency of salt marshes to sea level rise in the Northeastern U.S. Clim. Change 125(3-4): 501-509. doi:10.1007/s10584-014-1189-x

Weston, N.B. 2014. Declining sediments and rising seas: an unfortunate convergence for tidal wetlands. Estuaries Coasts 37(1): 1-23. doi: 10.1007/s12237-013-9654-8

Whigham, D.F., and Nusser, S.M. 1990. The response of Distichlis Spicata (L.) Greene and Spartina Patens (Ait.) Muhl. to nitrogen fertilization in hydrologically altered wetlands. In Wetland Ecology and Management: Case Studies. Edited by D.F. Whigham, R.E. Good, and J. Kvet. Spring, the Netherlands. pp. 31-38.

Wigand, C., McKinney, R.A., Charpentier, M.A., Chintala, M.M., and Thursby, G.B. 2003. Relationships of nitrogen loadings, residential development, and physical 
characteristics with plant structure in New England salt marshes. Estuaries 26(6): 1494-1504. doi:10.1007/BF02803658.

Wigand C. 2008. Coastal salt marsh community change in Narragansett Bay in response to cultural eutrophication. In Science for ecosystem-based management.Edited by A. Desbonnet, B.A. Costa-Pierce BA. Springer, New York, NY. pp 499-521.

Wigand, C., Brennan, P., Stolt, M., Holt, M., and Ryba, S. 2009. Soil respiration rates in coastal marshes subject to increasing watershed nitrogen loads in southern New England, USA. Wetlands 29(3): 952-963. doi:10.1672/08-147.1 


\section{Figure Legends}

Figure 1. Tides were simulated in $700 \mathrm{~L}$ tanks using pumps and standpipes to produce a semidiurnal microtidal range of $20 \mathrm{~cm}$, in accordance with field-measured marsh groundwater variations (Watson et al., 2014).

Figure 2. Growth response of $S$. patens and D. spicata (in monoculture pots) to fertilization and inundation treatments: (A) aboveground biomass, (B) tiller height, (C) tiller density, (D) belowground biomass, $(\mathrm{E})$ rhizome biomass, $(\mathrm{F})$ root biomass, and $(\mathrm{G})$ ratio of supported biomass (shoots, rhizomes) to root biomass (RSB/RB). Error bars show standard error ( $n$ of 6, per treatment). Capital letters denote where significant differences were found between inundation treatments by two-way ANOVA. Lower case letters denote significant differences between fertilized vs. unfertilized (from two-way ANOVA) and/or significant differences found by the simple main effects ANOVA.

Figure 3. Boxplots showing changes in shoot abundance for $S$. patens in mixed S. patens/D. spicata pots $(N=24)$ pots over the course of the experiment in relation to nutrient and inundation treatments. Boxes denote median and interquartile range, while whiskers denote full distribution. A Wilcoxon signed ranks exact test revealed a significant increase in the proportion of $S$. patens for the unfertilized high elevation treatment $\left(\mathrm{W}^{+}=19 ; \mathrm{p}<0.05\right)$, and a significant decrease in the proportion of $S$. patens for the low elevation fertilized treatment $\left(\mathrm{W}^{+}=1 ; \mathrm{p}<0.05\right)$. Shifts in D. spicata were the inverse of those found for S. patens. These significant differences are denoted by astericks.

Figure 4. Photosynthetic response of $S$. patens and D. spicata (in monoculture pots) to fertilization and inundation treatments: (A) $\mathrm{CO}_{2}$ uptake normalized to area in the leaf 
chamber; (B) photochemical efficiency $\left(\mathrm{F}_{\mathrm{v}} / \mathrm{F}_{\mathrm{m}}\right)$; and $(\mathrm{C})$ soil $\mathrm{CO}_{2}$ flux measured at the end of the experiment, a community respiration estimate. Error bars show standard error ( $n$ of 6 , per treatment). Capital letters denote where significant differences were found between inundation treatments by two-way ANOVA. Lower case letters denote significant differences between fertilized vs. unfertilized (from two-way ANOVA) and/or significant differences found by the simple main effects ANOVA.

Figure 5. Histograms showing the distribution of porewater sulfide and dissolved inorganic nitrogen (DIN) concentrations for nutrient and elevation treatments: (A) high elevation, unfertilized; (B) high elevation, fertilized; (C) low elevation, unfertilized; (D) low elevation, fertilized.

Figure 6. Nitrogen concentrations ( $\mathrm{mg} \mathrm{g}^{-1}$ dry weight, mean $\pm \mathrm{SE}, N=6$ per treatment) for $S$. patens and D. spicata shoots in monoculture and mixture pots. Using a two-way ANOVA, significant differences were found between monocultures and mixtures $(F=5.799, p=0.018)$ and by species. $(F=8.746, p=0.004)$.

Figure 7. Relationships between field conditions present in five Rhode Island coastal wetlands with respect to elevation and nutrient availability, and the presence of D. spicata and $S$. patens, growing singly and in combination. Panels A through $\mathrm{C}$ show the distribution of marsh elevations where vegetation is present (A), and the distribution of elevations where D. spicata (B) and S. patens (C) are present. Panels D through F show the relationship between overall median marsh elevation and the percentage cover of $S$. patens $(S P)$ and $D$. spicata (DS) (D), and relationships between nutrient availability and cover of $S$. patens (E), 
and D. spicata $(\mathrm{F})$. Relationships between vegetation patterns and nutrient availability were significant at the $p<0.10$ level. 


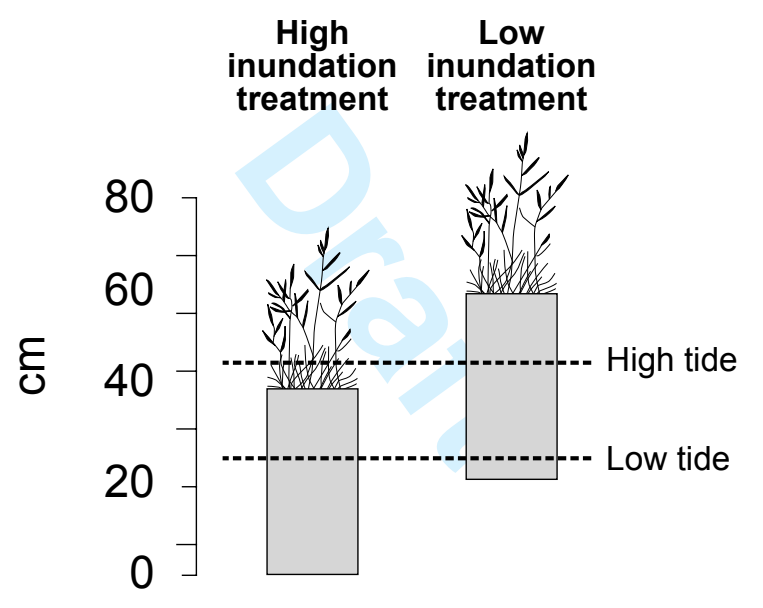


Spartina patens Distichlis spicata

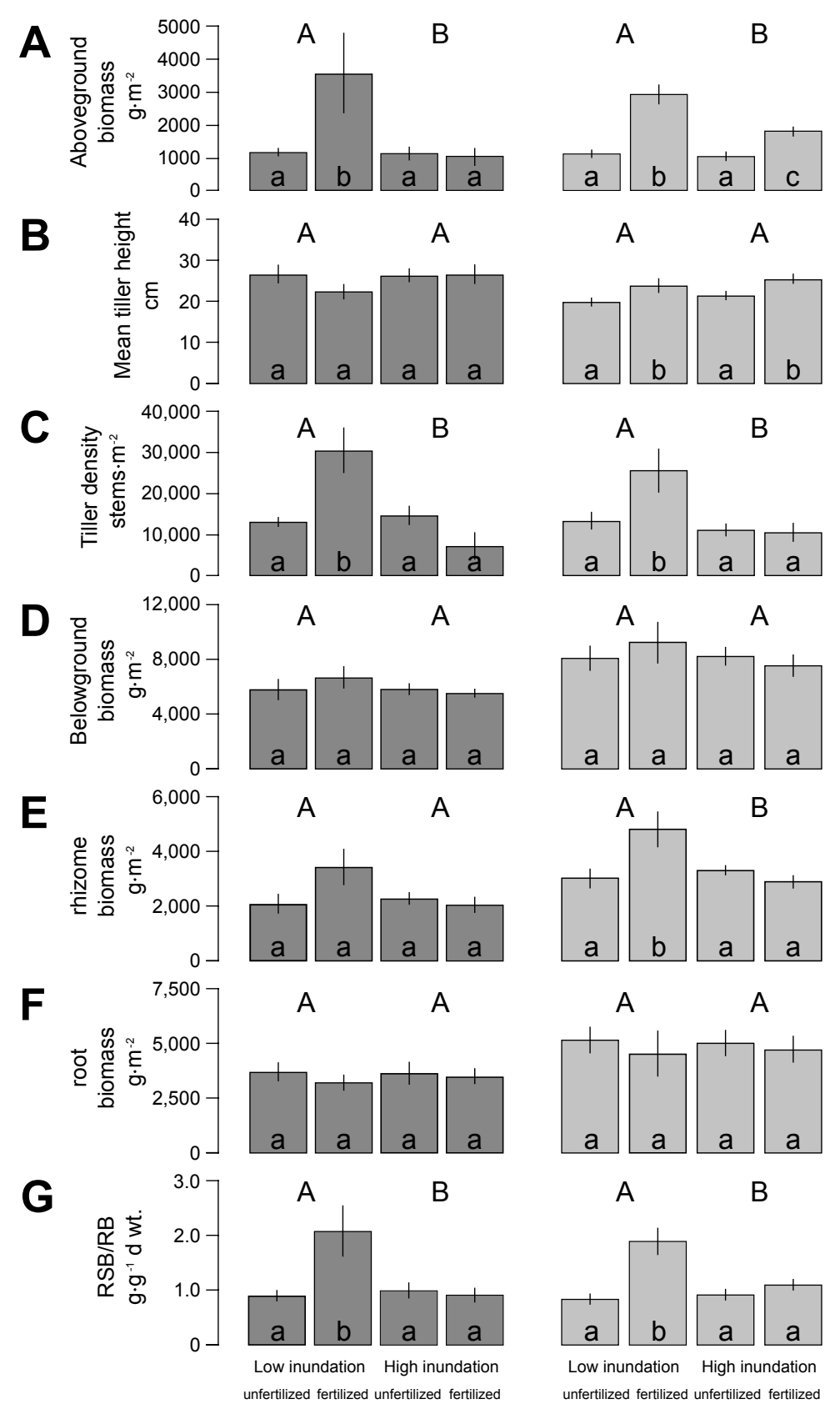


Change in relative proportion of $S$. patens in mixed pots

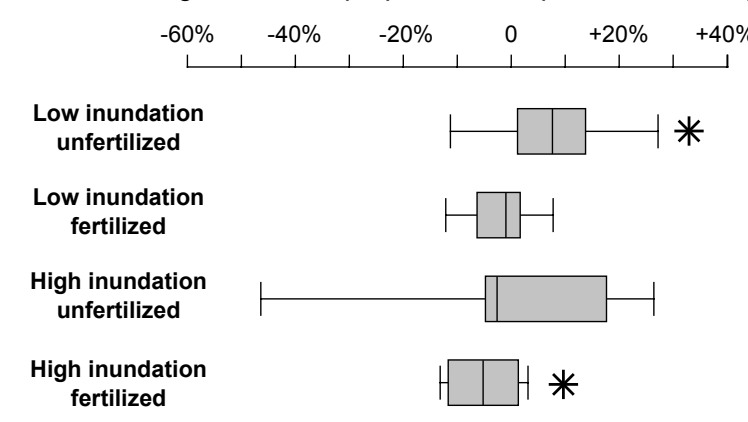




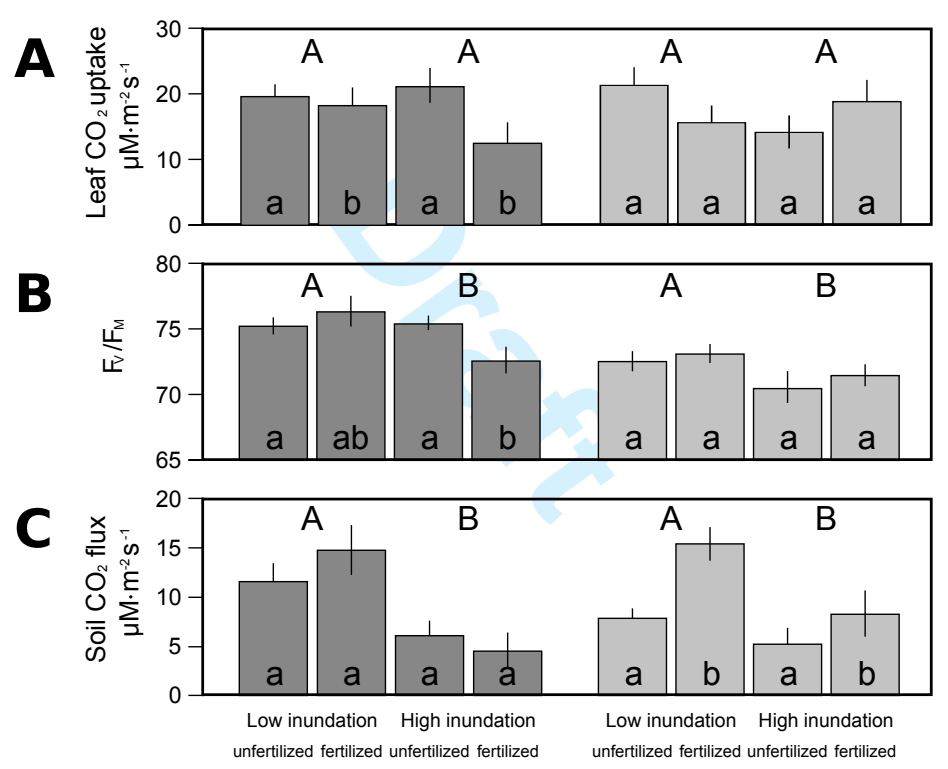


Porewater $\mathrm{H}_{2} \mathrm{~S} \quad$ Porewater $\mathrm{NH}_{4}^{+}$

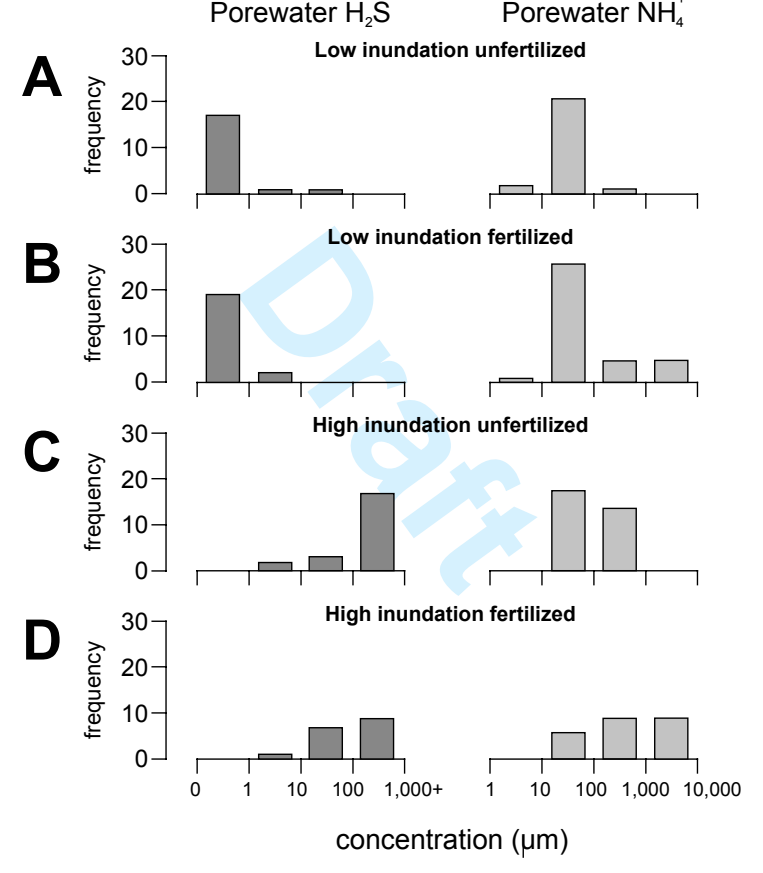




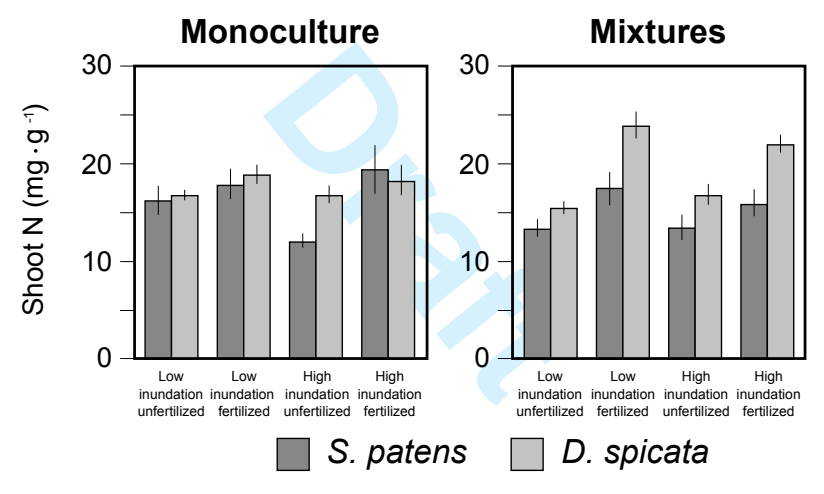

https://mc06.manuscriptcentral.com/botany-pubs 

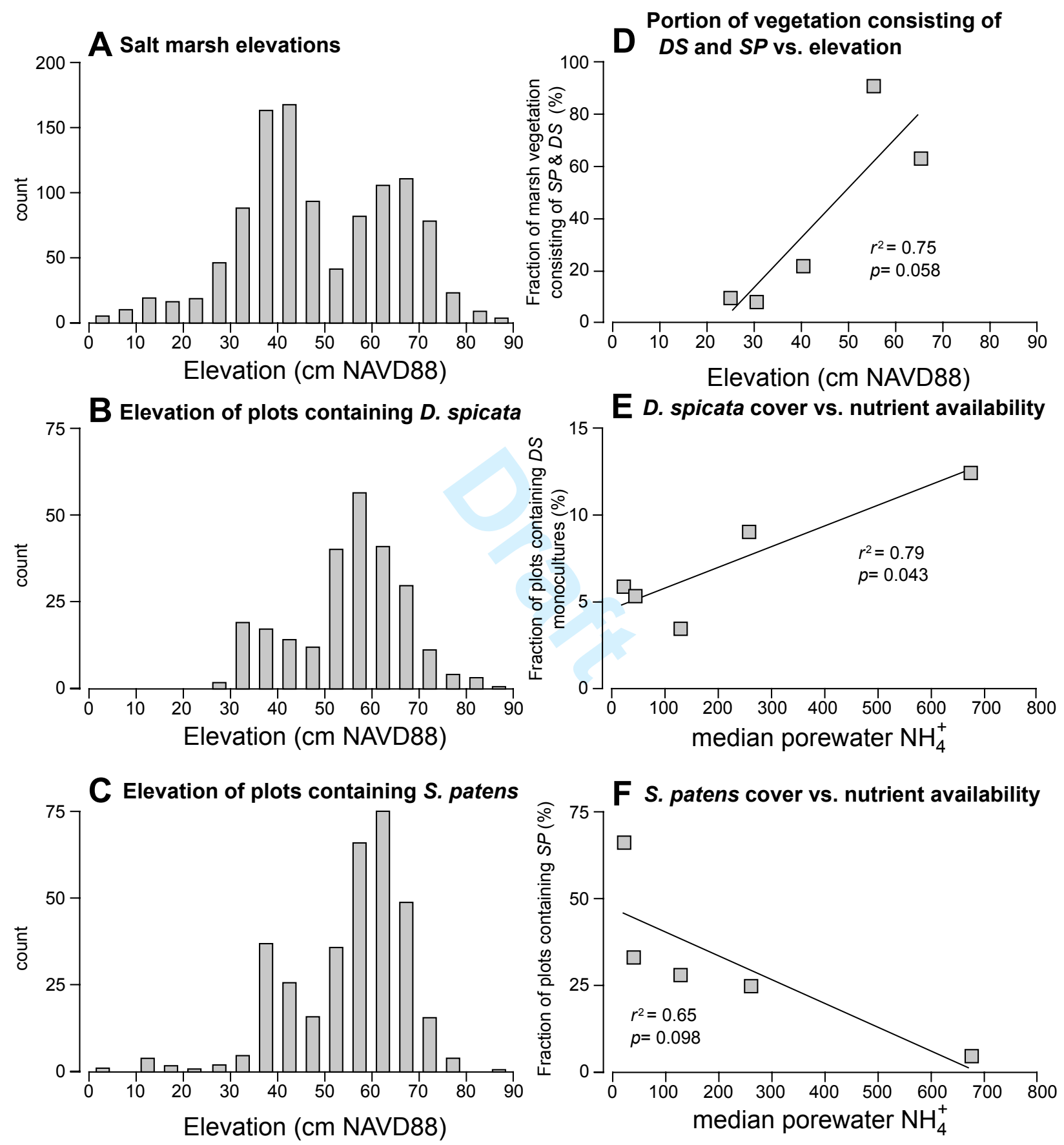